\title{
In vitro antioxidant properties of herb decoction extracts derived from Epirus, Greece
}

\author{
ZOI SKAPERDA ${ }^{1 *}$, IOANNIS D. KYRIAZIS ${ }^{1 *}$, PERIKLIS VARDAKAS ${ }^{1}$, FOTIOS TEKOS $^{1}$, \\ KONSTANTINA ANTONIOU ${ }^{2}$, NIKOLAOS GIANNAKEAS ${ }^{3}$ and DIMITRIOS KOURETAS ${ }^{1}$ \\ ${ }^{1}$ Department of Biochemistry-Biotechnology, University of Thessaly, 41500 Larissa; ${ }^{2}$ Genetics Unit, \\ Papageorgiou General Hospital, 56429 Thessaloniki; ${ }^{3} \mathrm{Q}$ Base R\&D, Science and Technology Park of Epirus, \\ University of Ioannina Campus, 45110 Ioannina, Greece
}

Received August 19, 2021; Accepted November 4, 2021

DOI: $10.3892 /$ ijfn.2021.21

\begin{abstract}
For thousands of years, medicinal herbs have been an integral part of traditional medicine, since a number of them exhibit potent antioxidant properties, mainly associated with their rich content in bioactive compounds. Based on these attributes, nowadays, medicinal herbs are used for industrial purposes (e.g., as natural food additives) and are also evaluated as chemopreventive strategies for diseases associated with the disruption of redox homeostasis. In that frame, the aim of the present study was to appraise the redox properties of various medicinal or edible herbs originating from the region of Epirus in Greece. The antioxidant, reducing and antigenotoxic effects of herb decoction extracts were evaluated using a series of in vitro cell-free assays. Whereupon, non-cytotoxic concentrations of the four most potent herb decoction extracts (i.e., Origanum vulgare, Salvia officinalis, Aloysia citrodora and Rosmarinus officinalis) were used to treat EA.hy926 endothelial cells, and the glutathione (GSH) and reactive oxygen species (ROS) levels were determined using flow cytometry in order to detect the potential changes induced in the intracellular redox equilibrium. The results indicated that apart from the Rosmarinus officinalis decoction extract, which did not induce any changes following treatment, the decoction extracts of Origanum vulgare $(50 \mu \mathrm{g} / \mathrm{ml})$ and Salvia officinalis (10 and $20 \mu \mathrm{g} / \mathrm{ml})$ induced a significant decrease in GSH levels compared with the controls, while the decoction extract of Aloysia citrodora was the most bioactive, inducing a significant decrease in GSH levels at all concentrations used $(5,10$ and $20 \mu \mathrm{g} / \mathrm{ml})$. On the whole, the tested herb decoction extracts exhibited a potent antioxidant capacity.
\end{abstract}

Correspondence to: Professor Dimitrios Kouretas, Department of Biochemistry-Biotechnology, University of Thessaly, Viopolis, Mezourlo, 41500 Larissa, Greece

E-mail:dkouret@uth.gr

*Contributed equally

Key words: antioxidants, oxidative stress, cell lines, Greek herbs
In addition, the most robust of these were able to disrupt the antioxidant mechanisms of the EA.hy926 cell line, as revealed by the depletion of the intracellular GSH levels, rendering them promising contenders for further studies.

\section{Introduction}

Medicinal plants have attained a commanding role in the global health care system as sources of various phytochemicals, several of which possess potent antioxidant properties. Such products cover a large part of the global market, exceeding $\$ 100$ billion annually and this coverage is expected to reach $\$ 550$ billion by 2030 with a compound annual growth rate of $18.9 \%$ (1). The World Health Organization (WHO) has reported that $80 \%$ of the Earth's population relies on traditional medicine for their primary health care needs, and a main part of this therapy involves the use of plant extracts and their active compounds (2). Specifically, for the past 3,000 years, the therapeutic principles of the active compounds of medicinal herbs have established their importance in health practices in traditional medicine in China, India and Africa, which has been ascertained as such by Western standards. In consonance with the definition adopted by the WHO, traditional medicine refers to 'the sum total of the knowledge, skill, and practices based on the theories, beliefs, and experiences indigenous to different cultures, whether explicable or not, used in the maintenance of health as well as in the prevention, diagnosis, improvement or treatment of physical and mental illness' (3). During the period between 1950-1970, 100 plant-based drugs were introduced to the US drug market, including vincristine, a plant alkaloid, composing a chemotherapy medication used as a treatment for several types of cancer (4).

Natural products offer a plethora of advantages to the drug development process compared to conventional synthetic compounds. To begin with, natural products can be found in high abundance in nature, allowing scientists to yield almost endless quantities of these. Notably, natural products have a higher structural complexity and scaffold diversity than typical synthetic small-molecule libraries (5). Moreover, due to their structural diversity and optimization via co-evolution in biological systems, natural products have increased their probability to interact with proteins, an important characteristic 
lending them potent chemopreventive properties (6). On the other hand, despite their rapid action, synthetic drugs are often associated with adverse effects that negatively affect the human body in the long-term (7).

Synthetic antioxidants were the food industries first candidates used to counteract the potential adverse effects of various food products on the health of consumers $(8,9)$. However, questions involving their nutritional value and potential toxic side-effects, rapidly led to emerging concerns with respect to human safety $(10,11)$. At the same time, herb-derived secondary metabolites, that are commonly associated with notable biological characteristics, such as antioxidant, antimicrobial and antimutagenic activities, have been given precedence in the use of natural antioxidants. Of note, natural antioxidants are capable of exerting these beneficial properties at micromolar concentrations either via the direct scavenging of free radicals or through the induction of hormetic mechanisms (12). Therefore, the consequent reduction of oxidative modifications, and the prevention of mutagenesis, carcinogenesis and aging, constitute the robust argument of using plant-derived antioxidants against the synthetic ones (13).

Several methodologies have been developed for the purpose of evaluating the antioxidant capacity of crude natural extracts or pure isolated chemical compounds that are derived from natural sources $(14,15)$. Within this context, 47 natural extracts derived from routinely used medicinal or edible herbs from the Epirus region in Greece were screened in terms of their antioxidant properties. On that note, the total phenolic content of herb decoctions, as well as their antioxidant, reducing and antigenotoxic activities were evaluated using a series of in vitro cell-free assays. Subsequently, non-cytotoxic concentrations of the four most potent herb decoction extracts were used to treat EA.hy 926 endothelial cells in order to examine their effects on the intracellular redox status by measuring the reduced glutathione (GSH) and reactive oxygen species (ROS) levels. Thus, the proposed study, will allow us to identify herbs that possess promising antioxidant capacity in order to be introduced in follow-up studies that will use in vivo models of oxidative stress-mediated diseases.

\section{Materials and methods}

Chemicals, reagents and cell culture medium. All the herbs were derived from local producers in the Epirus region of Greece. To determine the total phenolic content, Folin-Ciocalteu reagent and gallic acid were purchased from Sigma-Aldrich; Merck KGaA. For the appraisal of the antiradical and reducing activities of the herb decoction extracts, 2,2'-azinobis-(3-ethylbenzthiazoline-6-sulfonic acid) (ABTS), horseradish peroxidase (HRP), hydrogen peroxide $\left(\mathrm{H}_{2} \mathrm{O}_{2}\right)$ solution $30 \%$, methanol $(\mathrm{MeOH}), 1,1$-diphenyl-2-picrylhydrazyl (DPPH'), ferric chloride, 2-deoxyribose, nicotinamide adenine dinucleotide (NADH), nitroblue tetrazolium (NBT) and phenazine methosulfate (PMS) were obtained from Sigma-Aldrich; Merck KGaA. Furthermore, trichloroacetic acid (TCA) and 2-thiobarbituric acid (TBA) were obtained from Merck KGaA. To estimate the potential antigenotoxic properties, pBluescript $(\mathrm{SK}+)$ plasmid DNA was purchased from Stratagene; Agilent Technologies, Inc. and 2,2'-azobis(2-amidinopropane) dihydrochloride (AAPH) from Sigma-Aldrich; Merck KGaA.
With respect to the tested cell line, EA.hy926 endothelial cells were donated by Professor George Koukoulis (University of Thessaly, Larissa, Greece). For cell cultures, Dulbecco's modified Eagle's medium (DMEM), fetal bovine serum (FBS), phosphate-buffered saline (PBS) and trypsin-EDTA solution $0.25 \%$ were purchased from Gibco; Thermo Fischer Scientific, Inc. The TACS XTT Cell Proliferation assay kit was purchased from R\&D Systems, Inc. Finally, to determine the intracellular GSH and ROS levels, mercury orange and 2,7-dichlorofluorescein diacetate (DCF-DA) were purchased from Sigma-Aldrich; Merck KGaA. All solvents were of analytical grade.

Herb decoctions. To prepare herb decoction extracts, $2 \mathrm{~g}$ of dry herb leaves were added to $200 \mathrm{ml}$ tap water, followed by boiling for $3 \mathrm{~min}$. Subsequently, the boiled samples were allowed to stand for $5 \mathrm{~min}$. The resulting decoction was filtered, followed by lyophilization of the total filtrate. The yield of the products following extraction is presented Table SI. The lyophilized product was used to prepare the final decoction in which the polyphenolic content and bioactivity were evaluated.

Total phenolic content (TPC). The TPC of the samples was determined using Folin-Ciocalteu reagent. Briefly, $1 \mathrm{ml} \mathrm{dH_{2 }} \mathrm{O}$, $100 \mu \mathrm{l}$ Folin-Ciocalteu reagent and $20 \mu \mathrm{l}$ of each sample were added to test tubes and the mixture was incubated for $3 \mathrm{~min}$ at $25^{\circ} \mathrm{C}$ under dark conditions. Subsequently, $280 \mu 1$ of a


added, followed by incubation for $1 \mathrm{~h}$ at $25^{\circ} \mathrm{C}$ under ambient conditions in the dark, and the absorbance was then determined at $765 \mathrm{~nm}$ using a spectrophotometer (Hitachi, U-1900 UV/VIS, Hitachi High-Technologies Corporation). A test tube containing Folin-Ciocalteu reagent and $\mathrm{dH}_{2} \mathrm{O}$ was used as a blank. The phenolic content was determined using a standard curve of gallic acid $(0,50,150,250$ and $500 \mu \mathrm{g} / \mathrm{ml})$, and the results are expressed as mg of gallic acid per $g$ of dry sample.

$D P P H^{\bullet}$ radical scavenging assay. The radical scavenging capacity (RSC) of the tested herb decoctions was evaluated using a slightly modified method of the $\mathrm{DPPH}^{\bullet}$ assay (16), as previously described (17). Briefly, $50 \mu \mathrm{l}$ of the tested samples at various concentrations was mixed with $900 \mu \mathrm{l}$ of methanol $(\mathrm{MeOH})$, and subsequently $50 \mu \mathrm{l}$ of a freshly prepared methanolic solution of 2,2-diphenyl-1-picrylhydrazyl radical $\left(\mathrm{DPPH}^{\circ}\right)(2 \mathrm{mM})$ was added. The samples were incubated for $20 \mathrm{~min}$ in the dark at room temperature, and the absorbance was then determined at $517 \mathrm{~nm}$ using a spectrophotometer (Hitachi, U-1900 UV/VIS, Hitachi High-Technologies Corporation). Furthermore, $\mathrm{MeOH}$ was used as a blank and the free radical solution alone in $\mathrm{MeOH}$ was used as a control. The percentage RSC of the tested samples was calculated using the following equation: $\% \mathrm{RCS}=\left[\left(\mathrm{OD}_{\text {control }}-\mathrm{OD}_{\text {sample }}\right) / \mathrm{OD}_{\text {control }}\right]$ $\mathrm{x} 100$, where $\mathrm{OD}_{\text {control }}$ and $\mathrm{OD}_{\text {sample }}$ refer to the absorbance values of the control and the tested sample, respectively. To compare the radical scavenging efficiency of the different herb decoctions, an $\mathrm{IC}_{50}$ (half maximal inhibitory concentration) value was estimated.

ABTS $^{\bullet+}$ radical scavenging assay. The $\mathrm{ABTS}^{\bullet+} \mathrm{RSC}$ of the tested samples was determined as previously described by 
Cano (18), with some minor modifications $(17,19)$. Briefly, $500 \mu \mathrm{l}$ ABTS $(1 \mathrm{mM}), 50 \mu \mathrm{H}_{2} \mathrm{O}_{2}(30 \mu \mathrm{M}), 50 \mu \mathrm{l} \mathrm{HRP}$

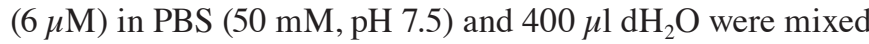
together, vortexed and incubated for $45 \mathrm{~min}$ in the dark at room temperature. Subsequently, $50 \mu 1$ of the tested samples were added, and the absorbance was monitored spectrophotometrically at $730 \mathrm{~nm} \mathrm{~nm}$ using a spectrophotometer (Hitachi, U-1900 UV/VIS, Hitachi High-Technologies Corporation). For each experiment, the mixture without HRP was used as a blank, while the mixture without the tested sample was used as a control. The percentage RSC was determined using the same equation as the one described above for the $\mathrm{DPPH}^{\circ}$ assay. Finally, an $\mathrm{IC}_{50}$ value was estimated to compare the RSC of the different herb decoctions.

Superoxide radical scavenging assay. The superoxide anion radical scavenging ability of the herb decoctions was assessed using the method of Gülçin et al (20) with some modifications (19). The system of PMS, NADH and NBT was used for the generation of superoxide radicals. Briefly, $125 \mu \mathrm{l} \mathrm{NBT}(300 \mu \mathrm{M}), 125 \mu \mathrm{l} \mathrm{NADH}(468 \mu \mathrm{M})$ and $50 \mu \mathrm{l}$ of the tested samples at various concentrations were added to a test tube containing $625 \mu 1$ Tris- $\mathrm{HCl}$ buffer $(16 \mathrm{mM}$, $\mathrm{pH}$ 8.0). The reaction began following the addition of $125 \mu \mathrm{l}$ of PMS $(60 \mu \mathrm{M})$ to the mixture. A vigorous vortex followed, as well as a 5-min incubation at room temperature. Finally, the absorbance was measured spectrophotometrically at using a spectrophotometer (Hitachi, U-1900 UV/VIS, Hitachi High-Technologies Corporation). In each experiment, a sample without PMS and the tested sample was used as a blank, while a sample without the sample was used as a control. The superoxide anion RSC of the tested samples was calculated using the equation described above. Eventually, an $\mathrm{IC}_{50}$ value was estimated to compare the radical scavenging efficiency of the different herb decoctions.

Reducing power assay. The reducing power capacity was determined according to the method described in the study by Yen and Duh (21) with minor modifications (19). Briefly, $50 \mu 1$ of the tested samples at different concentrations were mixed with $200 \mu \mathrm{l}$ of phosphate buffer (0.2 M, pH 6.6) and $250 \mu \mathrm{l}$ of potassium ferricyanide $(1 \% \mathrm{w} / \mathrm{v})$ in $\mathrm{dH}_{2} \mathrm{O}$. The reaction mixture was placed in a dry bath incubator at $50^{\circ} \mathrm{C}$ for $20 \mathrm{~min}$. The samples were then placed on ice for an additional $5 \mathrm{~min}$. Subsequently, $250 \mu$ l of TCA (10\%) were added, and the samples were centrifuged at $900 \mathrm{x}$ g for $10 \mathrm{~min}$ at $25^{\circ} \mathrm{C}$. Subsequently, $700 \mu 1$ of the supernatant were transferred to new test tubes

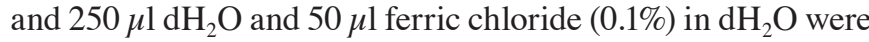
added. The mixtures were incubated at room temperature for $10 \mathrm{~min}$. Finally, the absorbance was determined spectrophotometrically at $700 \mathrm{~nm}$ using a spectrophotometer (Hitachi, U-1900 UV/VIS, Hitachi High-Technologies Corporation). An $\mathrm{AU}_{0.5}$ value was extrapolated using graph-plotted absorbance against the sample concentration, indicating the sample concentration that causes an absorbance of 0.5 .

Peroxyl radical-induced DNA plasmid strand cleavage. The assay was performed using a procedure previously described (22) with some modifications as reported by Priftis et al (23). Peroxyl radicals (ROO*) were generated via the thermal decomposition of AAPH. The reaction mixture (10 $\mu \mathrm{l})$ containing $1 \mu \mathrm{g}$ pBluescript $(\mathrm{SK}+)$ plasmid DNA, $2.5 \mathrm{mM}$ AAPH in PBS and the tested samples at various concentrations was incubated in the dark for $45 \mathrm{~min}$ at $37^{\circ} \mathrm{C}$. It should be noted that a negative control consisting of plasmid DNA and PBS, and a positive control containing plasmid DNA, PBS and AAPH were also used. Subsequently, $3 \mu 1$ loading buffer (bromophenol blue $0.25 \%+30 \%$ glycerol) were added to terminate the reaction, and the samples were loaded on a $0.8 \%$ (w/v) agarose gel. The samples ran at $80 \mathrm{~V}$ for $55 \mathrm{~min}$. Ethidium bromide $(10 \mathrm{mg} / \mathrm{ml})$ was used as intercalating dye. The acquisition of images was achieved using a MultiImage Light Cabinet (Alpha Innotech Corporation). Finally, the Alpha View suite was used to analyze the UV exposed gels. The percentage inhibition of peroxyl radicals by the tested herb decoctions was estimated through the following equation: \% Inhibition $=\left[\left(\mathrm{S}-\mathrm{S}_{\mathrm{o}}\right) /\left(\mathrm{S}_{\text {control }^{-}} \mathrm{S}_{\mathrm{o}}\right)\right] \times 100$, where $\mathrm{S}$ represents the percentage of the supercoiled plasmid DNA in the tested samples, whereas $S_{0}$ refers to the percentage of the supercoiled plasmid DNA in the positive control. Additionally, $\mathrm{S}_{\text {control }}$ represents the percentage of the supercoiled DNA in the negative control. An $\mathrm{IC}_{50}$ value was determined to compare the efficacy of different herb decoctions against the peroxyl radical-induced DNA damage.

Cells and cell culture. Following the cell-free based assays and the characterization of the antioxidant properties of the tested herb decoctions, the four most potent herb decoction extracts were assessed for their cytotoxic and intracellular antioxidant properties in the EA.hy926 cell line. EA.hy926 is a stable human endothelial cell line derived by hybridizing human umbilical vein endothelial cells, namely human umbilical vein endothelial cells (HUVECs), with the A549 human lung carcinoma cells. The endothelial cells were cultured in $25 \mathrm{~cm}^{2}$ tissue culture flasks and incubated for $24 \mathrm{~h}$ at $37^{\circ} \mathrm{C}$ in $5 \% \mathrm{CO}_{2}$ and $80-95 \%$ humidity to reach $\sim 70-80 \%$ confluency. The cell culture medium used was DMEM containing $1 \mathrm{~g} / \mathrm{l}$ D-glucose, $4 \mathrm{mM}$ L-glutamine and supplemented with $10 \%$ (v/v) FBS, 100 units/ml penicillin and 100 units/ml streptomycin. A morphology examination at high and low culture densities was conducted using a microscope (Kern, OCL251, KERN \& SOHN GmbH; data not shown) to authenticate the state of cells, through their phenotypic characteristics. According to the international guidelines on good cell culture practice (24), the cell line used was checked for mycoplasma using PCR and it was mycoplasma-free.

XTT cell viability assay. Cell viability was assessed using the XTT assay kit (R\&D Systems, Inc.). Briefly, $10^{4}$ cells were seeded into a 96-well plate with their respective complete medium. Following a 24-h incubation, the cells were treated with increasing concentrations of the Epirus herb decoctions in serum-free medium for an additional $24 \mathrm{~h}$. Subsequently, $50 \mu \mathrm{l}$ of the XTT test solution were prepared by mixing $50 \mu \mathrm{l}$ XTT-labeling reagent with $1 \mu \mathrm{l}$ XTT activator, and $50 \mu \mathrm{l}$ of the XTT test solution were added to each well. Following a 4-h incubation, the optical density was measured at 450 and $630 \mathrm{~nm}$ (reference wavelength) using a microplate reader (Bio-Tek ELx800; Bio-Tek Instruments, Inc.). Cell cultures in serum-free medium were used as a 
negative control. Moreover, the absorbance of every tested sample concentration alone in serum-free medium and XTT test solution was also measured at $450 \mathrm{~nm}$ using a plate reader (EL808; BioTek Instruments, Inc.). The absorbance values that were obtained in wells that contained only herb decoctions extracts were subtracted from the ones that acquired from wells that contained the respective extract concentration and seeded cells. Data were calculated as follows: Cell viability $(\%$ of control $)=\left(\mathrm{OD}_{\text {sample }} / \mathrm{OD}_{\text {control }}\right) \times 100$, where $\mathrm{OD}_{\text {control }}$ and $\mathrm{OD}_{\text {sample }}$ indicate the optical density of the negative control and the test compounds, respectively. All experiments were carried out in duplicate and at least on two separate occasions.

Flow cytometric analysis of GSH and ROS levels. The endothelial cells were seeded in $25 \mathrm{~cm}^{2}$ culture flasks for GSH and ROS determination and incubated for $24 \mathrm{~h}$ at $37^{\circ} \mathrm{C}$ in $5 \% \mathrm{CO}_{2}$ and $80-95 \%$ humidity to reach about $70-80 \%$ confluency. The culture medium was then removed and replaced with serum-free medium containing the herb decoction extracts tested at different concentrations. Following a 24-h incubation, the cells were trypsinized, collected and washed twice following consecutive centrifugations at $300 \mathrm{x} \mathrm{g}$ for $10 \mathrm{~min}$ at $5^{\circ} \mathrm{C}$. After each centrifugation the supernatant was discarded, and the cellular pellet was resuspended in PBS. After the second wash the cellular pellet $\left(10^{6}\right.$ cells $\left./ \mathrm{ml}\right)$ was ready for intracellular staining for determinations of $\mathrm{GSH}$ and ROS levels using flow cytometry with mercury orange and DCF-DA, respectively. The fluorescent mercury orange binds directly to GSH, whereas DCF-DA is deacetylated by esterases within the cells, and is further converted to fluorescent DCF by the oxidative action of ROS. A $400 \mu \mathrm{M}$ stock solution of mercury orange was created in acetone and stored at $4^{\circ} \mathrm{C}$, while a fresh $400 \mu \mathrm{M}$ stock solution of DCF-DA was prepared in methanol. To assess the GSH and ROS levels, the cells $\left(10^{6}\right.$ cells $\left./ \mathrm{ml}\right)$ were resuspended in PBS and incubated in the presence of mercury orange $(40 \mu \mathrm{M})$ or DCF-DA $(10 \mu \mathrm{M})$ in the dark at $37^{\circ} \mathrm{C}$ for $30 \mathrm{~min}$. Following incubation, the cells were washed with PBS to remove the excess dye, centrifuged (300 x g, $10 \mathrm{~min}, 4^{\circ} \mathrm{C}$ ) and resuspended in PBS. The cells were then submitted to flow cytometric analysis using a FACSCalibur flow cytometer (BD Biosciences) with excitation and emission length at 488 and $530 \mathrm{~nm}$ for ROS, and at 488 and $580 \mathrm{~nm}$ for GSH. Forward angle and right-angle light scattering representable of the cells size and cell internal complexity, respectively, were measured. Analyses were performed on 10,000 cells per sample, at a flow rate of 1,000 events/sec, and fluorescence intensities were measured on a logarithmic scale. Data were analyzed using BD Cell Quest software 6.0 (BD Biosciences). Each experiment was repeated at least three times.

Statistical analyses. For in vitro cell-free based assays, an $\mathrm{IC}_{50}$ or $\mathrm{AU}_{0.5}$ value for each tested sample was estimated. Each experiment was conducted in triplicate and on two separate occasions. As regards the cell culture experiments, duplicates of the cell replicate and two separate occasions were used. Data were analyzed using one-way ANOVA followed by Dunnett's tests for multiple pairwise comparisons, using the statistical package SPSS (version 21.0; SPSS, Inc.). All data are presented as the mean \pm SEM and a value of $\mathrm{P}<0.05$ was considered to indicate a statistically significant difference.

\section{Results}

In vitro cell-free measurements for the assessment of the antioxidant, reducing and antigenotoxic capacity of the herb decoction extracts

TPC. Initially, the TPC of all the herb decoction extracts, that were supplied to us by Epirus local producers, was determined. According to the results, the highest polyphenolic content was observed in the sage extract (Salvia officinalis; code 30 ). Furthermore, a high phenolic content $(>0.8 \mathrm{mg}$ gallic acid $/ \mathrm{ml}$ ) was found in decoction extracts derived from perforate St. John's wort (Hypericum perforatum; codes 4 and 19), rosemary (Rosmarinus officinalis; code 45), spearmint (Mentha spicata, code 28), hawthorn (Crataegus monogyna, code 23), garden thyme (Thymus vulgaris; code 40), ironwort (Sideritis scardica; code 2), lemon beebrush (Aloysia citrodora; code 18) and pennyroyal (Mentha pulegium, code 14) (Table I).

Determination of $\mathrm{IC}_{50}$ values of extracts in $\mathrm{DPPH}^{\bullet}, \mathrm{ABTS}^{\bullet+}$ and superoxide radical scavenging assays. According to the $\mathrm{DPPH}^{\bullet}$ assay, the decoction extract that derived from oregano (Origanum vulgare; code 46) displayed the highest scavenging activity $(6.6 \mu \mathrm{g} / \mathrm{ml})$ (Table I). Following that, several other extracts were found to scavenge half of the DPPH radical at concentrations $<20 \mu \mathrm{g} / \mathrm{ml}$. Among these, lemon beebrush (Aloysia citrodora; code 18), perforate St. John's wort (Hypericum perforatum; code 4), and rosemary (Rosmarinus officinalis; code 45) were also rich in phenol content, as described above. Of note, all the rosemary extracts that were tested, derived from three different producers (code 32, 33 and 45), exhibited an $\mathrm{IC}_{50}$ value $<20 \mu \mathrm{g} / \mathrm{ml}$, whereas all 10 different types of oregano [nine non-biologically cultivated (codes 35, 36, 37, 39, 41, 43, 44, 46 and 47) and one biologically cultivated (code 34 )] exhibited an $\mathrm{IC}_{50}$ value $<25 \mu \mathrm{g} / \mathrm{ml}$ (Table I).

In the ABTS $^{\cdot+}$ assay, the extract derived from oregano (Origanum vulgare; code 46) again exerted the highest scavenging activity $(7.85 \mu \mathrm{g} / \mathrm{ml}$; Table I). Similarly, all extracts that were derived from oregano [nine non-biologically cultivated (codes 35, 36, 37, 39, 41, 43, 44, 46 and 47) and one biologically cultivated (code 34)], exhibited potent scavenging activities against $\mathrm{ABTS}^{\bullet+}$ with $\mathrm{IC}_{50}$ values $<15 \mu \mathrm{g} / \mathrm{ml}$. Even though the lemon balm (Melissa officinalis) extracts were not that rich in phenol content, they displayed high $\mathrm{ABTS}^{\cdot+}$ scavenging activity (code $8,8.33 \mu \mathrm{g} / \mathrm{ml}$; code $21,8.95 \mu \mathrm{g} / \mathrm{ml}$; code 22 ; $9.06 \mu \mathrm{g} / \mathrm{ml})$. On the contrary, the decoction extract derived from lemon beebrush (Aloysia citrodora; code 18) exhibited a high $\mathrm{ABTS}^{\bullet+}$ scavenging activity $(8.29 \mu \mathrm{g} / \mathrm{ml})$ following its ability to scavenge $\mathrm{DPPH}^{\circ}$ and its high phenol content.

In the superoxide assay, the extract that was derived from sage (Salvia officinalis; code 13) displayed the highest efficacy $(6.5 \mu \mathrm{g} / \mathrm{ml})$, albeit its polyphenol content was one of the lowest detected $(0.44 \mathrm{mg} \mathrm{GA} / \mathrm{ml})$ (Table I). Even though the sage extracts from different producers had a high polyphenolic content, their efficacy to scavenge superoxide anion was diminished. Similarly, lemon balm extract (Melissa officinalis; code 21) that exhibited the second higher efficacy against superoxide anion radicals $(9 \mu \mathrm{g} / \mathrm{ml})$, was the one with the lowest polyphenol content among the three lemon 


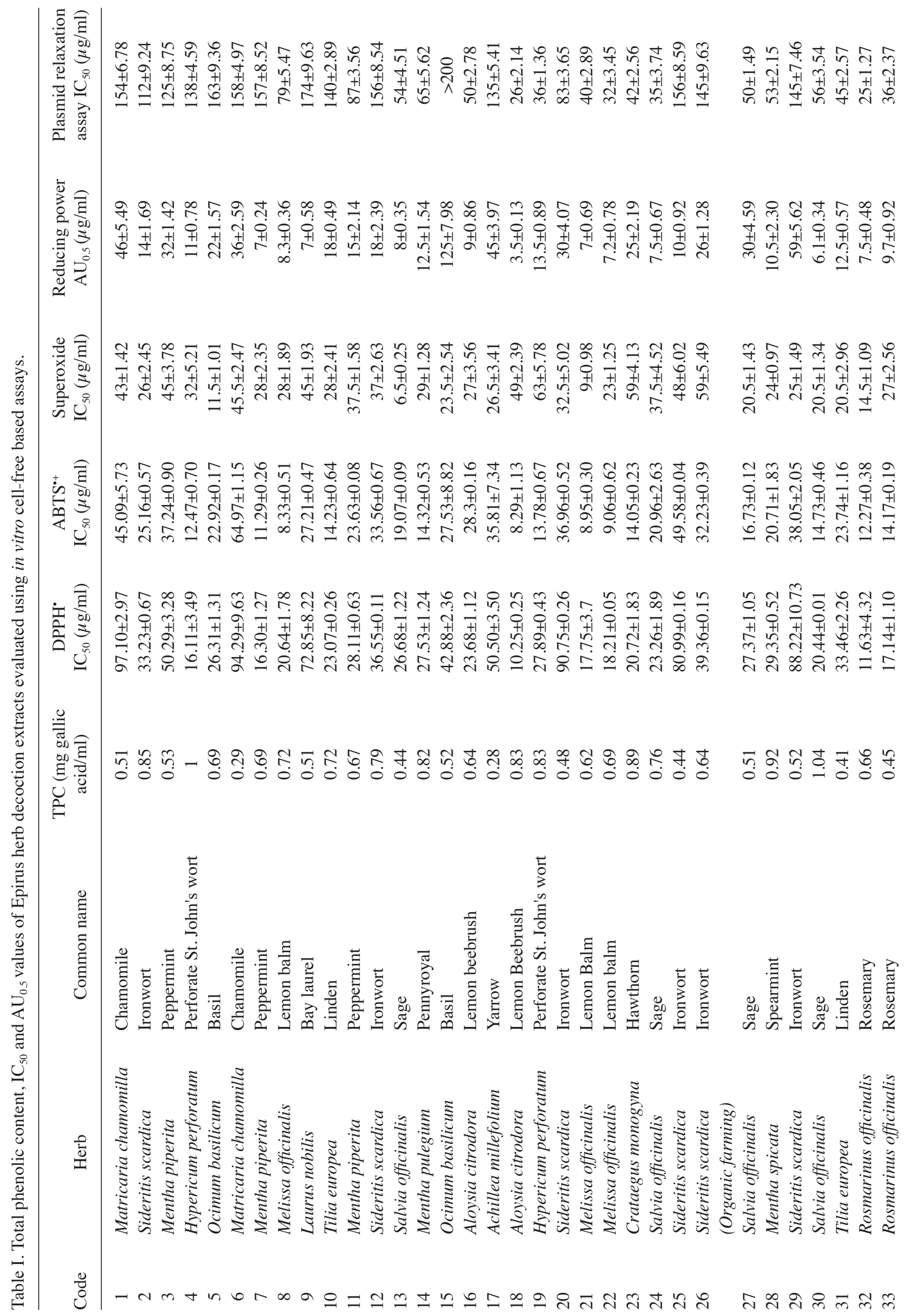




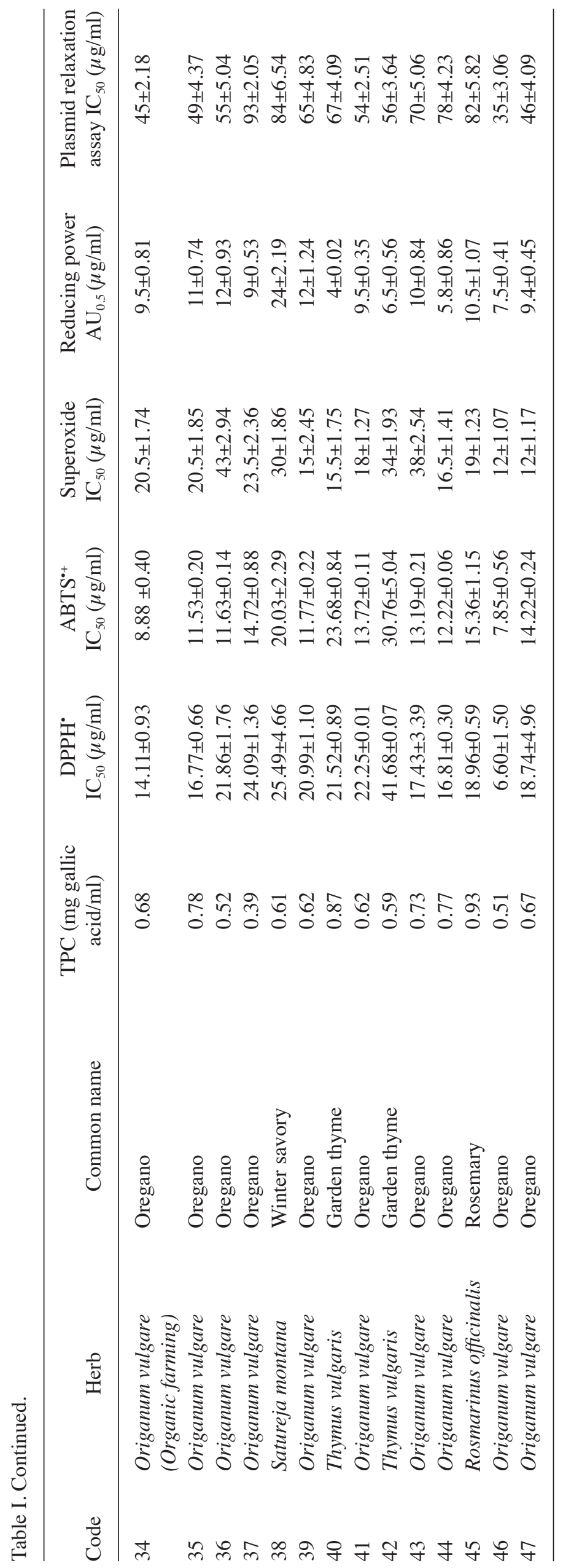




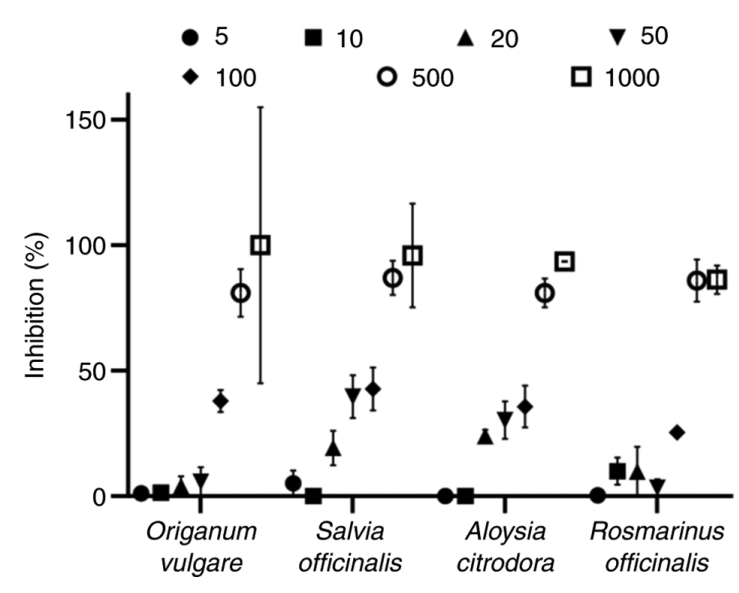

Figure 1. Cytotoxic concentration threshold $(\mu \mathrm{g} / \mathrm{ml})$ of Origanum vulgare, Salvia officinalis, Aloysia citrodora and Rosmarinus officinalis in EA.hy926 cells, as assessed using XTT assay. All symbols indicate the concentrations of the Epirus herb decoction extracts.

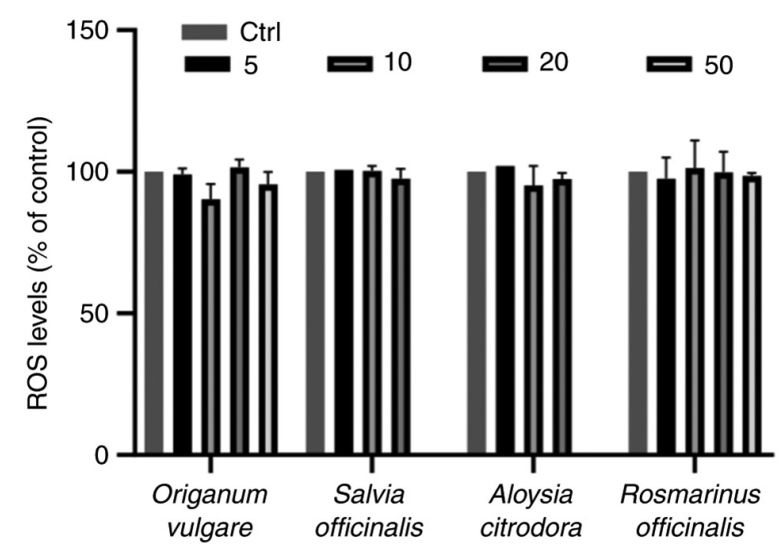

Figure 2. Effects of Origanum vulgare, Salvia officinalis, Aloysia citrodora and Rosmarinus officinalis decoction extracts on ROS levels in EA.hy926 cells after $24 \mathrm{~h}$. ROS, reactive oxygen species.

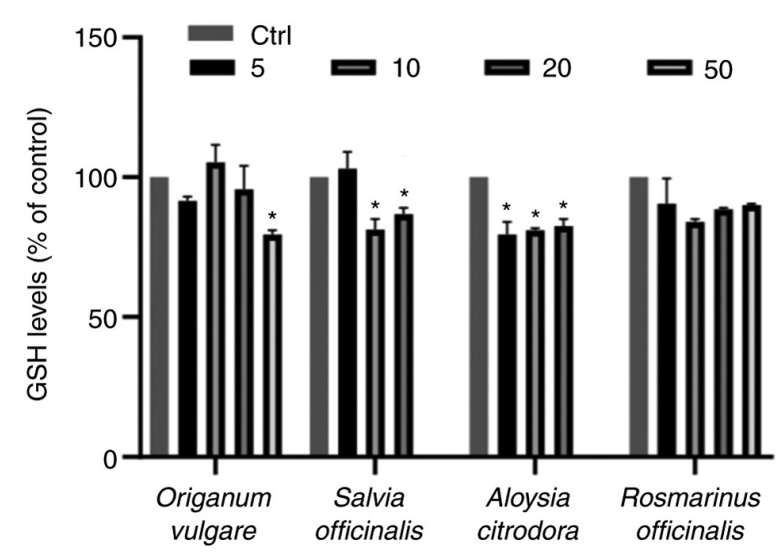

Figure 3. Effects of Origanum vulgare, Salvia officinalis, Aloysia citrodora and Rosmarinus officinalis decoction extracts on GSH levels in EA.hy926 cells after $24 \mathrm{~h}$. ${ }^{*} \mathrm{P}<0.05$, significant difference between the respective experimental and control group. GSH, glutathione.

balm extracts tested. Subsequently, basil (Ocimum basilicum, $11.5 \mu \mathrm{g} / \mathrm{ml}$ ) extract (code 5) and two of the oregano (Origanum vulgare; $12 \mu \mathrm{g} / \mathrm{ml}$ in both of them) extracts (codes
46 and 47) exhibited a potent efficacy to scavenge superoxide anion radicals. Of note, oregano with code 46 exhibited the highest activity against $\mathrm{DPPH}^{\bullet}$ and $\mathrm{ABTS}^{\bullet+}$, as described above.

Determination of reducing power capacity. The extract that exhibited the highest reducing power capacity was the one derived from lemon beebrush (Aloysia citrodora; code 18, $3.5 \mu \mathrm{g} / \mathrm{ml}$ ) (Table I). The same extract displayed a high polyphenol content and was also one of the most potent as regards the $\mathrm{DPPH}^{\bullet}$ and $\mathrm{ABTS}^{\bullet+}$ scavenging activity. Subsequently, an increased reducing power was exerted by both garden thyme (Thymus vulgaris; 4 and $6.5 \mu \mathrm{g} / \mathrm{ml}$, codes 40 and 42 , respectively). More specifically, the garden thyme extract with code 40 was one of the highly enriched in polyphenol extracts among the ones we tested. All extracts that derived from oregano had robust reducing power capacity ranging from 5.8 up to $12 \mu \mathrm{g} / \mathrm{ml}$. Furthermore, three out of the four sage extracts and all three lemon balm (Melissa officinalis; codes 8, 21 and 22) extracts exhibited an almost similar reducing power capacity (6.1-8 and 7-8.3 $\mu \mathrm{g} / \mathrm{ml}$, respectively). Other extracts that sporadically exhibited a potent reducing power capacity were extracts derived from peppermint (Mentha piperita; code 7, $7 \mu \mathrm{g} / \mathrm{ml}$ ) and bay laurel (Laurus nobilis; code 9, $7 \mu \mathrm{g} / \mathrm{ml}$ ).

Antigenotoxic activity of herb decoction extracts via plasmid relaxation assay. The plasmid relaxation assay revealed that rosemary (Rosmarinus officinalis; code 32) and lemon beebrush (Aloysia citrodora; code 18) extracts from the same producer had the most potent antigenotoxic activity of 25 and $26 \mu \mathrm{g} / \mathrm{ml}$, respectively (Table I). Similarly, another rosemary extract (code 33$)$ also exhibited a high activity $(36 \mu \mathrm{g} / \mathrm{ml})$ to protect plasmid DNA. Oregano (Origanum vulgare; code 46) extract, that displayed the highest efficacy against $\mathrm{DPPH}^{\bullet}$ and $\mathrm{ABTS}^{\cdot+}$ and one of the highest activities against superoxide anion radical, was also highly efficacious $(35 \mu \mathrm{g} / \mathrm{ml})$ to protect nucleic acids from single-strand breaks. Finally, two extracts derived from lemon balm (Melissa officinalis; codes 22 and 21, 32 and $40 \mu \mathrm{g} / \mathrm{ml}$, respectively), perforate St. John's wort (Hypericum perforatum; code 19, $36 \mu \mathrm{g} / \mathrm{ml}$ ) and sage (Salvia officinalis; code $24,35 \mu \mathrm{g} / \mathrm{ml}$ ) also exhibited a highly notable antigenotoxic activity.

In vitro cell-based measurements for the assessment of the herb decoction extracts antioxidant activity. Four of the extracts that displayed the highest cell-free antioxidant capacity in the methods tested were screened using the EA.hy 926 cells for cytotoxicity and antioxidant-related parameters. More specifically, oregano (Origanum vulgare; code 46), sage (Salvia officinalis; code 13), lemon beebrush (Aloysia citrodora; code 18) and rosemary (Rosmarinus officinalis; code 32) extracts were the ones that were selected for more elaborate analysis for the determination of their in vitro cell-based antioxidant ability.

XTT cell proliferation assay. Initially, the authors wished to examine whether these four extracts exerted any cytotoxic effects. For this purpose, XTT cell proliferation assay was performed using EA.hy926 cells. The Origanum vulgare decoction extract exhibited an $\mathrm{IC}_{50}$ value of $191.81 \mu \mathrm{g} / \mathrm{ml}$ 
with $50 \mu \mathrm{g} / \mathrm{ml}$ being almost non-cytotoxic (Fig. 1). The Salvia officinalis decoction extract exerted a lower $\mathrm{IC}_{50}$ value $(154 \mu \mathrm{g} / \mathrm{ml})$ with $10 \mu \mathrm{g} / \mathrm{ml}$ to be the highest concentration that did not present any cytotoxic manifestation. Similarly, $10 \mu \mathrm{g} / \mathrm{ml}$ of the Aloysia citrodora decoction extract did not inhibit EA.hy926 cell proliferation, with the $\mathrm{IC}_{50}$ value determined at $228 \mu \mathrm{g} / \mathrm{ml}$ (data not shown). Finally, Rosmarinus officinalis decoction extract had an $\mathrm{IC}_{50}$ value of $285.35 \mu \mathrm{g} / \mathrm{ml}$ (data not shown), rendering it as the less cytotoxic among the four more efficacious extracts.

Determination of intracellular GSH and ROS levels. Subsequently, the present study examined whether sublethal concentrations of the herb decoction extracts were able to alter the intracellular levels of GSH and ROS, since they both play crucial roles in physiology, particularly in cells with a cancerous profile. The sublethal concentrations of all four herbs decoction extracts were unable to affect the ROS levels as compared with the control group (Figs. 2 and S1). On the contrary, three herb decoction extracts were able to decrease the GSH levels in the already intracellular distorted cancerous physiology in comparison with the control group. More specifically, $50 \mu \mathrm{g} / \mathrm{ml}$ oregano (Origanum vulgare) were able to significantly decrease the GSH levels as compared with the untreated cells (Figs. 3 and S2). Additionally, 10 and $20 \mu \mathrm{g} / \mathrm{ml}$ of sage (Salvia officinalis) decoction extract diminished GSH levels in EA.hy926 cells. The same effect was evident in treatments with lemon beebrush decoction extracts (Aloysia citrodora), in which all concentrations tested reduced the intracellularGSH levels significantly. On the contrary, all concentrations tested from rosemary (Rosmarinus officinalis) decoction extract did not affect the GSH levels.

\section{Discussion}

The present study aimed to determine the redox-related properties of well-known and routinely used herb decoctions derived from Epirus region, Greece, predominantly for their extensive use in everyday life, their integral part in human diet, and eventually for their potential exploitation as chemopreventive agents. The results suggest the potent antioxidant activity of Epirus medicinal and aromatic herbs. Moreover, the lack of cytotoxicity and the alterations induced in the GSH/ROS equilibrium represent promising paraphernalia for activity, strengthening the logic of using herbal decoctions as a prevention strategy against oxidative stress related diseases which currently stand out as the dominant threats of human health (25).

The range of the TPC in the tested decoctions was from $0.44 \mathrm{mg}$ gallic acid $/ \mathrm{ml}$ for the Sideritis scardica extract to $1.04 \mathrm{mg}$ gallic acid/ml for the Salvia officinalis. These levels differ compared to those in previous studies $(26,27)$, a discrepancy that may be attributed to the different extraction protocols, solvents, different microenvironment and cultivation processes used. Phenolic acids are a subclass of phenolic compounds, widely spread throughout the plant kingdom. In the present study, considerable variation was detected in phenolic compounds content among the different herb species. The high level of diversity and complexity of the natural mixtures of phenolic compounds that are present in herb decoctions render difficult to characterize every compound, elucidate its structure, and attribute its activity. Of note, further studies are required to identify the major groups and important aglycones of the phenolic compounds, allowing us to associate their presence with their enhanced activity like we have done in our previous study (28). Nonetheless, several medical herbs have been studied and to some extent their phenolic chemistry is known (29).

The potent antioxidant potential that the polyphenolic compounds of the herb decoctions possess is a manifestation that has been already reported (30). The chemical structure and type of the compounds, the level of substrate oxidation and the conditions of the oxidation process, constitute parameters that affect their activity (31). These compounds consist of a hydroxyl group and play a major role in the antioxidant capacity because of their ability to release hydrogen and to form stable radical intermediates. Moreover, the mechanism of their action mainly comprises neutralization of free radicals, enzyme induction and chelation of metal ions.

The experiments performed in the present study clearly indicated that the extracts of Origanum vulgare, Salvia officinalis, Rosmarinus officinalis and Aloysia citrodora possessed a potent antioxidant potential and may be stronger radical scavengers than the other tested Epirus herbs. In particular, it was found that Origanum vulgare exhibited an enhanced antioxidant potential in the $\mathrm{DPPH}^{\circ}$ and $\mathrm{ABTS}^{-+}$ assays. Given the fact that the aforementioned assays use both organic and water-based solvents, they allow for the evaluation if the antioxidant effect of both lipophilic and hydrophilic polyphenols $(32,33)$. Even though the oregano (Origanum vulgare) decoction extract exhibited a potent scavenging ability against superoxide radical, the highest efficiency was achieved by the sage (Salvia officinalis) decoction extract. Flavonoids contained in this herb extract have also been previously reported for their effectiveness against superoxide anions (34), that have been proven to harm cellular components (35), predominantly lipids, as they are involved in initiation of the lipid peroxidation process (36). Lemon beebrush (Aloysia citrodora) exhibitd the highest reducing power capacity among herbs tested, serving as a significant indicator of its potential antioxidant activity. Similarly, it was found to be one of the most efficacious in response to scavenge $\mathrm{DPPH}^{\circ}$ and $\mathrm{ABTS}^{\circ+}$ generating radicals. The reducing capacity composes a distinct mechanism by which antioxidants exert their activity together with chain initiation, decomposition of peroxides, reducing capacity and radical scavenging (37). A previous study also suggested that the ability of plant-derived decoctions to act as reducing agents and free radical scavengers or as quenchers of singlet oxygen formation was probably attributed to their potent antioxidant effectiveness in vitro (38). In consonance, some authors have ascertained the fact that phenolic compounds are able to chelate metal ions and report that intracellular binding of iron is responsible for the protection offered by flavonoids against $\mathrm{H}_{2} \mathrm{O}_{2}$-induced DNA damage (39). DNA damage, as defined by strand breakage in response to oxidative stress, was most effectively inhibited with the rosemary (Rosmarinus officinalis) decoction extract.

The results obtained herein correspond with those of other studies examining the antioxidant properties of the medicinal and aromatic herbs Origanum vulgare, Aloysia citrodora, Salvia officinalis and Rosmarinus officinalis. Taken together, 
their beneficial properties have been basically attributed to their major chemical compounds, such as carvacrol, thymol, diterpenes and carnosol (40). In particular, Origanum vulgare extract exhibits antioxidant and antibacterial activities, mostly attributed to its carvacrol and thymol content $(41,42)$. Furthermore, the antioxidant potential of Aloysia citrodora was evaluated in several scientific studies that have demonstrated the strong activity of this plant $(43,44)$. Additionally, decoctions derived from organ (shoots and hairy roots) and undifferentiated (cell and callus) cultures of Salvia officinalis, as well as from shoots and roots of in vitro regenerated plants, as well its chemical components, were evaluated for their antioxidant properties using several in vitro models $(45,46)$. Moreover, it has been demonstrated that Rosmarinus officinalis essential oil, apart from exhibiting free radical scavenging activity determined by $\mathrm{DPPH}^{*}$ assay, exerts its hepatoprotective effects through the activation of physiological defense mechanisms. The beneficial effects of this plant herb have been attributed to its main chemical constituents, including diterpenes, carnosol and carnosic acid, as well as to its essential oil components (47).

In the global literature, there is a constant debate as to the plant herb biologically active substances that can affect the activity and metabolism of cells. Cell-free methodologies are able to provide valuable preamble data concerning their efficacy; however, cell-based in vitro experiments are also used to minimize the mechanistic limitations of protocols using cell-free systems. Using cell lines integrates a spectrum of protective mechanisms represented by a shield of important cellular molecules against oxidants toxic effects that cell-free methodologies do not contain and examine. Hence, in the present study, the four decoction extracts that exhibited the most potent antioxidant activity in cell-free methodologies (Origanum vulgare, Salvia officinalis, Aloysia citrodora and Rosmarinus officinalis) were examined for their redox-related properties using human endothelial EA.hy926 cells.

The high energy demand of cancer cells, and concomitantly, their intense metabolic rates lead to abundant ROS production in the cellular environment, derived primarily from the mitochondria and the endoplasmic reticulum. Albeit the continuous and elevated ROS levels can result in the death of normal cells, through the induction of oxidative stress, the high rate of ROS generation in cancer cells is compensated by the equally high activation of the respective antioxidant mechanisms (48). Considering that the nuclear transcriptional factor, nuclear factor erythroid 2-related factor 2 (NRF2), enhances cell survival under oxidative stress conditions, its overactivation enables cancer cells to take advantage over the normal ones (49). In the case that the elevated levels of ROS cannot be alleviated, the cancer cells are vulnerable to cell death mediated by oxidative stress (48). In this context, strategies related to intracellular ROS generation or target endogenous antioxidant mechanisms have been tested as potential anticancer therapies $(50,51)$. As regards the polyphenol activity, it is known that these molecules exert a biphasic effect; at low concentrations, they act as antioxidants, whereas at high concentrations, they promote elevated oxidation that results in cytotoxicity (52).

To address the above, the present study evaluated the cytotoxicity exerted by the four most potent decoction extracts in order to determine the effects of non-cytotoxic concentrations of these on the intracellular GSH and ROS levels. The results from XTT assay revealed that Origanum vulgare and Rosmarinus officinalis decoctions exhibited significant cytotoxicity $>100 \mu \mathrm{g} / \mathrm{ml}$, whereas the cytotoxic threshold for Aloysia citrodora and Salvia officinalis decoctions extracts was $>50 \mu \mathrm{g} / \mathrm{ml}$.

The assessment of the effects of the extracts on the antioxidant capacity of endothelial cells was based on the measurement of the GSH and ROS levels using flow cytometry. The regulation of intracellular GSH levels following extract treatment is crucial, since GSH is considered a significant endogenous antioxidant molecule in cells (53). GSH can directly scavenge free radicals by donating one hydrogen atom from its sulfhydryl group or is used as substrate by antioxidant enzymes (53). For endothelial cells in particular, GSH is important not only as an antioxidant, but also as a crucial regulator of cell signaling $(54,55)$. Endothelial cells as part of the inflammatory tumor microenvironment play a critical role in inflammatory processes, since the secretion of endothelial mitogens and chemotactic factors driven by endothelial cells, stimulates their proliferation and angiogenesis (56). Endothelial cells release growth and survival factors (such as IL-6) to protect tumor cells (57). Consequently, the dependence of tumor growth and expansion to new blood vessels formed by proliferating endothelial cells warrants investigation. The latter implies the need for the examination of strategies targeting the functions of tumor endothelial cells as key players in angiogenic processes (58). Therefore, the assessment of the mechanisms through which medicinal herbs affect molecular pathways that regulate the GSH and ROS levels in the EA.hy926 cell line may be of utmost importance.

In the present study, the results revealed that Origanum vulgare decoction extract significantly decreased the GSH levels at $50 \mu \mathrm{g} / \mathrm{ml}$ compared with the control. It has been previously described that carvacrol and thymol are the components considered responsible for the antioxidant activity of the essential oil of oregano $(59,60)$. It was reported that carvacrol increases ROS and depletes GSH levels in two distinct human cell lines. In line with the above results, carvacrol has been reported to induce ROS levels in V79 cells (61) and to reduce the levels of antioxidant enzymes catalase (CAT) and superoxide dismutase (SOD) in HL-60 (human acute promyelocytic leukemia cells) and Jurkat (human T lymphocyte cells) cells (62). It is possible that their antitumor activity does not rely on the increase of intracellular ROS levels, but on the elevation of the difference between the GSH and ROS levels (63), rendering cells vulnerable to the already increased ROS levels due to their cancerous phenotype (64).

In the present study, Salvia officinalis decoction extract was also found to decrease the GSH levels at concentrations of 10 and $20 \mu \mathrm{g} / \mathrm{ml}$ compared with the control. Salvia officinalis may exert its cytotoxic effect in a similar manner to oregano. A previous study that investigated the effect of Salvia chloroleuca reported that was able to induce the apoptosis of MCF-7 human breast cells through a ROS-mediated pathway (65). The results of the present study and the previous one (65) are contradictory to data from previous literature that reported that HepG2 cells pre-treated with the 
Salvia officinalis extract formed less oxidant-induced DNA lesions (66). Although Kozics et al (66) proposed that the observed DNA-protective activity could be explained by both the elevation of glutathione peroxidase (GPx) activity in the pre-treated cells, as well as to its well documented in vitro antioxidant activity, their finding of an elevated GPx activity may justify the decrease levels of GSH found in the present study. Previously, Salvia officinalis was reported to decrease peripheral inflammation that may support blood brain barrier function and cerebral blood flow, contributing to longer-term benefits towards cognitive health in older adults (67).

In the present study, the Aloysia citrodora decoction extract also decreased the GSH levels in the EA.hy926 cell line at all concentrations tested $(5,10$ and $20 \mu \mathrm{g} / \mathrm{ml})$ in comparison with the control. Notably, Aloysia citrodora decoction extract has been previously linked to an increase in glutathione reductase (GR) levels accompanied by lower levels of malondialdehyde and protein carbonyls, as proposed by a double-blind study using human subjects (68). Furthermore, Fitsiou et al (69) reported potent anticancer and antimicrobial properties accompanied by a weak direct antioxidant activity, as shown by comet assay in Jurkat cells. Another study demonstrated results similar with to the data presented herein, attributing lemon beebrush leaf infusion as a source of compounds with significant free radical scavenger ability and antigenotoxic activity (70).

Even though Rosmarinus officinalis decoction extract exhibited a potent antioxidant capacity, the present study failed to detect any changes in GSH and ROS levels. As aforementioned, it has been demonstrated that the depletion of endogenous GSH levels is considered to increase the efficacy of therapeutic interventions $(71,72)$. Furthermore, it has been shown that Rosmarinus officinalis contains rosmarinic acid, and that its administration in a xenograft tumor model was able to suppress tumor growth (73). Furthermore, rosmarinic acid can damage murine melanoma cells through a double-axis effect, namely the possible protection of healthy cells (increased GSH) and the concomitant damage of cancer cells (depletion of GSH) (74).

The increase of the 'spare capacity' between the GSH and ROS levels in the cancer endothelial cell line, as proposed by the results of the present study may be part of a further disruption of their redox status compared to normal cells. This phenomenon may compose a critical step for the selection of appropriate chemopreventive strategies based on appropriate configurations of the redox potential of cancer cells. Chinese herbs have been associated with the metabolic reprogramming of cancer cells, enabling their experimental use as therapeutic compounds against metabolism-related diseases (75).

An uncertainty that the present study generates lies in the obvious discrepancy between results in decoctions examined in the authors' laboratory and originating from the same plant type, but have been provided by different producers. This could relate to the fact that herb biological properties are dependent on differences in the exact geographical location and cultivation micro-environment conditions. Previously, Karydas et al (76) reported that even different land areas can modulate antioxidant potential and polyphenolic content. More elaborately, the different land areas can be further fragmented into different habitats and the specific microclimate conditions that include altitude, soil composition, temperature variation, and watering during the day or night hours. Furthermore, even though the in vitro cell-free methodologies rely on the ability of the extract to scavenge the generating radical, small differences in the methodology mechanisms can justify the differentiation of the efficacies that each extract exhibits. This has been frequently reported in studies examining a series of protocol schemes (77-79). Therefore, it is necessary not to rely on a single test or even the analyzed parameter (80). These fluctuations in efficacies have not only been observed among experimental protocols applied, but also between herbs that were derived from different producers. Nevertheless, it is clear that certain decoction extracts (e.g., Origanum vulgare) have exhibited almost an constant antioxidant efficacy.

In conclusion, the results of the present study support the promising role of the tested decoctions as a source of antioxidant active compounds in follow-up in vivo studies, since they possess the ability to interfere with or modify the redox state of cells. Nevertheless, antioxidant protection involves a variety of factors, such as the concentration of antioxidant compounds, the synergetic effect that they may possess and how they can modulate the different branches of cellular oxidative status. Therefore, the scientific community needs to remain alert and acknowledge the aforementioned limitations that do not allow us to reach a solid outcome, which is also dependent on the methodology used to examine the extracts. Likewise, it is reasonable that the outcome in in vitro applications may differ from that in vivo due to advanced levels of complexity of the biological system. The need for further research focusing on the effects of medicinal and aromatic herbs in vivo is critical to corroborate the beneficial effects proposed by the present study. Additionally, the cytotoxicity and bioactivity of the samples examined appears to be dependent on various factors, such as a plant's geographical location and cultivation process, parts of the plant used for decoction preparation and the extraction protocol (solvent, temperature, time, etc.). However, clinical trials and primary prevention studies using high doses of such herbs in humans did not yield the expected beneficial outcome (81). Conclusively, the generating trend of the use of herbs in order to exert beneficial effects on human health and well-being requires further exploration. The setting of prerequisites for the investigation of the interrelation between particular herb harvests and cultivation conditions may lead to new dimensions and complexities that the scientific community needs to focus their interest and shed light on. Finally, the assessment of the polyphenol content in the decoction extracts that possess a higher efficacy and the identification of those molecules that may exert significant biological effects is of utmost importance. The aforementioned should be followed with mechanistic in vitro and in vivo experimental models that will elucidate the molecular mechanisms induced by the compounds.

\section{Acknowledgements}

Not applicable.

\section{Funding}

The present study was partly funded by the project entitled 'BioActHerb: A cloud-based platform for the bioactivity of 
herbs in Epirus Region', co-financed by the European Union and Greek national funds through the Operational Program for Research and Innovation Smart specialization Strategy (RIS3) of Ipeiros (Project Code: HP1AB-0028215).

\section{Availability of data and materials}

The datasets used and/or analyzed during the current study are available from the corresponding author on reasonable request.

\section{Authors' contributions}

ZS, IDK, PV and FT analyzed and interpreted the data regarding the antioxidant activity of the herbs. ZS, IDK and PV were major contributors to the writing of the manuscript. $\mathrm{KA}, \mathrm{NG}$ and DK, were involved in the design and conception of the study, and also confirm the authenticity of all the raw data. All authors read and approved the final manuscript.

\section{Ethics approval and consent to participate}

Not applicable.

\section{Patient consent for publication}

Not applicable.

\section{Competing interests}

DK is an Editor of the journal, but had no personal involvement in the reviewing process, or any influence in terms of adjudicating on the final decision, for this article. The other authors declare that they have no competing interests.

\section{References}

1. GlobeNewswire by notified: Global Medicinal Herbs Market Size, Trends, Company Profiles, Growth Rate, Revenue, Demand and Forecast. GlobeNewswire, Inc., 2021. https://www.globe newswire.com/en/news-release/2021/02/16/2176036/0/en/HerbalMedicine-Market-Global-Sales-Are-Expected-To-Reach-US-550Billion-by-2030-as-stated-by-insightSLICE.html.

2. Joshi B, Sah GP, Basnet BB, Bhatt MR, Sharma D, Subedi K, Pandey J and Malla R: Phytochemical extraction and antimicrobial properties of different medicinal plants: Ocimum sanctum (Tulsi), Eugenia caryophyllata (Clove), Achyranthes bidentata (Datiwan) and Azadirachta indica (Neem). J Microbiol Antimicrob 3: 1-7, 2011

3. World Health Organization (WHO): WHO Traditional Medicine Strategy: 2014-2023. WHO, Geneva, 2013. https://apps.who.int/ iris/handle/10665/92455.

4. Garg AK, Faheem M and Singh S: Role of medicinal plant in human health disease. Asian J Plant Sci Res 11: 19-21, 2021.

5. Galloway WRJD, Isidro-Llobet $A$ and Spring DR: Diversity-oriented synthesis as a tool for the discovery of novel biologically active small molecules. Nat Commun 1: 80, 2010.

6. Hopkins AL, Mason JS and Overington JP: Can we rationally design promiscuous drugs? Curr Opin Struct Biol 16: 127-136, 2006.

7. Ekor M: The growing use of herbal medicines: Issues relating to adverse reactions and challenges in monitoring safety. Front Pharmacol 4: 177, 2014.

8. Sindhi V, Gupta V, Sharma K, Bhatnagar S, Kumari R and Dhaka N: Potential applications of antioxidants-A review. J Pharm Res 7: 828-835, 2013

9. Kebede $\mathrm{M}$ and Admassu S: Application of antioxidants in food processing industry: Options to improve the extraction yields and market value of natural products. Adv Food Technol Nutr Sci Open J 5: 38-49, 2019.
10. Taghvaei $\mathrm{M}$ and Jafari S: Application and stability of natural antioxidants in edible oils in order to substitute synthetic additives. J Food Sci Technol 52: 1272-1282, 2015.

11. Augustyniak A, Bartosz G, Cipak A, Duburs G, Horáková L, Luczaj W, Majekova M, Odysseos AD, Rackova L, Skrzydlewska E, et al: Natural and synthetic antioxidants: An updated overview. Free Radic Res 44: 1216-1262, 2010.

12. Mattson MP: Dietary factors, hormesis and health. Ageing Res Rev 7: 43-48, 2008.

13. Mossa ATH and Nawwar GAM: Free radical scavenging and antiacetylcholinesterase activities of Origanum majorana L. essential oil. Hum Exp Toxicol 30: 1501-1513, 2011.

14. Veskoukis A, Kerasioti E, Priftis A, Kouka P, Spanidis Y, Makri S and Kouretas D: A battery of translational biomarkers for the assessment of the in vitro and in vivo antioxidant action of plant polyphenolic compounds: The biomarker issue. Curr Opin Toxicol 13: 99-109, 2019.

15. Kyriazis I, Skaperda Z, Tekos F, Makri S, Vardakas P, Vassi E, Patouna A, Terizi K, Angelakis C and Kouretas D: Methodology for the biofunctional assessment of honey (Review). Int J Funct Nutr 2: 2634-7989, 2021.

16. Brand-Williams W, Cuvelier ME and Berset C: Use of a free radical method to evaluate antioxidant activity. LWT-Food Sci Technol 28: 25-30, 1995.

17. Kouka P, Priftis A, Stagos D, Angel is A, Stathopoulos P, Xinos N, Skaltsounis AL, Mamoulakis C, Tsatsakis AM, Spandidos DA and Kouretas D: Assessment of the antioxidant activity of an olive oil total polyphenolic fraction and hydroxytyrosol from a Greek Olea europea variety in endothelial cells and myoblasts. Int J Mol Med 40: 703-712, 2017.

18. Cano A: An end-point method for estimation of the total antioxidant activity in plant material. Phytochem Anal 9: 196-202, 1998.

19. Vardakas P, Skaperda Z, Tekos F, Trompeta AF, Tsatsakis A, Charitidis CA and Kouretas D: An integrated approach for assessing the in vitro and in vivo redox-related effects of nanomaterials. Environ Res 197: 111083, 2021.

20. Gülçin I, Küfrevioğlu ÖI, Oktay M and Büyükokuroğlu ME: Antioxidant, antimicrobial, antiulcer and analgesic activities of nettle (Urtica dioica L.). J Ethnopharmacol 90: 205-215, 2004.

21. Yen GC and Duh PD: Antioxidative properties of methanolic extracts from peanut hulls. J Am Oil Chem Soc 70: 383-386, 1993.

22. Hu C, Zhang Y and Kitts DD: Evaluation of antioxidant and prooxidant activities of bamboo phyllostachys nigra var. Henonis Leaf Extract in vitro. J Agric Food Chem 48: 3170-3176, 2000.

23. Priftis A, Stagos D, Konstantinopoulos K, Tsitsimpikou C, Spandidos DA, Tsatsakis AM, Tzatzarakis MN and Kouretas D: Comparison of antioxidant activity between green and roasted coffee beans using molecular methods. Mol Med Rep 12: 7293-7302, 2015.

24. Bal-Price A and Coecke S: Guidance on good cell culture practice (GCCP). Neuromethods 56: 1-25, 2011.

25. Tiwari AK: Imbalance in antioxidant defence and human diseases: Multiple approach of natural antioxidants therapy. Curr Sci 81: 1179-1187, 2001.

26. Lakka A, Bozinou E, Makris DP and Lalas SI: Evaluation of pulsed electric field polyphenol extraction from vitis vinifera, sideritis scardica and crocus sativus. ChemEngineering 5: 25, 2021.

27. Khiya Z, Oualcadi Y, Gamar A, Berrekhis F, Zair T and Hilali FEL: Correlation of total polyphenolic content with antioxidant activity of hydromethanolic extract and their fractions of the Salvia officinalis leaves from different regions of Morocco. J Chem 2021: 8585313, 2021.

28. Tekos F, Makri S, Skaperda ZV, Patouna A, Terizi K, Kyriazis ID, Kotseridis Y, Mikropoulou EV, Papaefstathiou G, Halabalaki M and Kouretas D: Assessment of antioxidant and antimutagenic properties of red and white wine extracts in vitro. Metabolites 11: 436, 2021.

29. Cai Y, Luo Q, Sun M and Corke H: Antioxidant activity and phenolic compounds of 112 traditional Chinese medicinal plants associated with anticancer. Life Sci 74: 2157-2184, 2004.

30. Carneiro de Siqueira K, Garcia LF, Lobón GS, Thomaza DV, Moreno EKG, de Carvalho MF, Rocha ML, dos Santos WTP and de Souza Gil E: Antioxidant activity evaluation of dried herbal extracts: An electroanalytical approach. Rev Bras Farmacogn 28: 325-332, 2018.

31. Santos-Sánchez NF, Salas-Coronado R, Villanueva-Cañongo C and Beatriz HC: Antioxidant Compounds and Their Antioxidant Mechanism. IntechOpen, London, 2019. https://www.intechopen. com/chapters/66259. Accessed March 22, 2019. 
32. Zegarac JP, Zulj LV, Stipčević T and Martinez S: Electrochemical determination of antioxidant capacity of fruit tea infusions. Food Chem 121: 820-825, 2010.

33. Oliveira-Neto JR, Rezende SG, de Fátima Reis C, Benjamin SR, Rocha ML and de Souza Gil E: Electrochemical behavior and determination of major phenolic antioxidants in selected coffee samples. Food Chem 190: 506-512, 2016.

34. Robak J and Gryglewski RJ: Flavonoids are scavengers of superoxide anions. Biochem Pharmacol 37: 837-841, 1988.

35. Korycka-Dahl M and Richardson T: Photogeneration of superoxide anion in serum of bovine milk and in model systems containing riboflavin and amino acids. J Dairy Sci 61: 400-407, 1978.

36. Ighodaro OM and Akinloye OA: First line defence antioxidants-superoxide dismutase (SOD), catalase (CAT) and glutathione peroxidase (GPX): Their fundamental role in the entire antioxidant defence grid. Alexandria J Med 54: 287-293, 2018.

37. Yildirim A, Mavi A, Oktay M, Kara AA, Algur OF and Bilaloglu V: Comparison of antioxidant and antimicrobial activities of tilia (Tilia argentea Desf ex DC), sage (Salvia triloba L.), and black tea (Camellia sinensis) extracts. J Agric Food Chem 48: 5030-5034, 2000.

38. Komaki A, Hoseini F, Shahidi S and Baharlouei N: Study of the effect of extract of Thymus vulgaris on anxiety in male rats. J Tradit Complement Med 6: 257-261, 2016.

39. Melidou M, Riganakos K and Galaris D: Protection against nuclear DNA damage offered by flavonoids in cells exposed to hydrogen peroxide: The role of iron chelation. Free Radic Biol Med 39: 1591-1600, 2005.

40. Ngo SNT, Williams DB and Head RJ: Rosemary and cancer prevention: Preclinical perspectives. Crit Rev Food Sci Nutr 51: 946-954, 2011

41. Hrnčič MK, Cör D, Simonovska J, Knez Ž, Kavrakovski Z and Rafajlovska V: Extraction techniques and analytical methods for characterization of active compounds in origanum species. Molecules 25: 4735, 2020.

42. Coccimiglio J, Alipour M, Jiang ZH, Gottardo C and Suntres Z: Antioxidant, antibacterial, and cytotoxic activities of the ethanolic Origanum vulgare extract and its major constituents. Oxid Med Cell Longev 2016: 1404505, 2016.

43. Bilia AR, Giomi M, Innocenti M, Gallori S and Vincieri FF: HPLC-DAD-ESI-MS analysis of the constituents of aqueous preparations of verbena and lemon verbena and evaluation of the antioxidant activity. J Pharm Biomed Anal 46: 463-470, 2008

44. Casanova E, García-Mina JM and Calvo MI: Antioxidant and antifungal activity of Verbena officinalis L. leaves. Plant Foods Hum Nutr 63: 93-97, 2008.

45. Grzegorczyk I, Matkowski A and Wysokińska H: Antioxidant activity of extracts from in vitro cultures of Salvia officinalis L. Food Chem 104: 536-541, 2007.

46. Miura K, Kikuzaki H and Nakatani N: Antioxidant activity of chemical components from sage (Salvia officinalis L.) and Thyme (Thymus vulgaris L.) measured by the oil stability index method. J Agric Food Chem 50: 1845-1851, 2002

47. Rašković A, Milanović I, Pavlović N, Ćebović T, Vukmirović S and Mikov M: Antioxidant activity of rosemary (Rosmarinus officinalis L.) essential oil and its hepatoprotective potential. BMC Complement Altern Med 14: 225, 2014.

48. Schieber M and Chandel NS: ROS function in redox signaling and oxidative stress. Curr Biol 24: R453-R462, 2014

49. Panieri E, Buha A, Telkoparan-Akillilar P, Cevik D, Kouretas D, Veskoukis A, Skaperda Z, Tsatsakis A, Wallace D, Suzen S and Saso L: Potential applications of NRF2 modulators in cancer therapy. Antioxidants (Basel) 9: 193, 2020.

50. Kang SW, Lee $S$ and Lee EK: ROS and energy metabolism in cancer cells: Alliance for fast growth. Arch Pharmacal Res 38 338-345, 2015

51. Skaperda Z, Tekos F, Makri S, Angelakis C, Vassi E, Vardakas P, Patouna A, Terizi K, Kyriazi D and Kouretas D: A novel combined bioactivity/chemoactivity holistic approach for the evaluation of dietary supplements. Food Chem Toxicol 152: 112159, 2021.

52. Mileo A and Miccadei S: Polyphenols as modulator of oxidative stress in cancer disease: New therapeutic strategies. Oxid Med Cell Longev 2016: 6475624, 2016.

53. Aquilano K, Baldelli S and Ciriolo MR: Glutathione: New roles in redox signaling for an old antioxidant. Front Pharmacol 5: 196, 2014.

54. Elliott SJ and Koliwad SK: Redox control of ion channel activity in vascular endothelial cells by glutathione. Microcirculation 4: 341-347, 1997
55. Espinosa-Díez C, Miguel V, Vallejo S, Sánchez FJ, Sandoval E, Blanco E, Cannata P, Peiró C, Sánchez-Ferrer CF and Lamas S: Role of glutathione biosynthesis in endothelial dysfunction and fibrosis. Redox Biol 14: 88-99, 2018.

56. Folkman J and Camphausen $\mathrm{K}$ : What does radiotherapy do to endothelial cells? Science 293: 227-228, 2001.

57. Rak JW, St Croix BD and Kerbel RS: Consequences of angiogenesis for tumor progression, metastasis and cancer therapy. Anticancer Drugs 6: 3-18, 1995.

58. Bussolati B, Deregibus MC and Camussi G: Characterization of molecular and functional alterations of tumor endothelial cells to design anti-angiogenic strategies. Curr Vasc Pharmacol 8: 220-232, 2010

59. Vardar-Unlü G, Candan F, Sökmen A, Daferera D, Polissiou M, Sökmen M, Dönmez E and Tepe B: Antimicrobial and antioxidant activity of the essential oil and methanol extracts of Thymus pectinatus Fisch. et Mey. Var. pectinatus (Lamiaceae). J Agric Food Chem 51: 63-67, 2003.

60. Bozin B, Mimica-Dukic N, Simin N and Anackov G: Characterization of the volatile composition of essential oils of some lamiaceae spices and the antimicrobial and antioxidant activities of the entire oils. J Agric Food Chem 54: 1822-1828, 2006.

61. Ündeğer Ü, Başaran A, Degen GH and Başaran N: Antioxidant activities of major thyme ingredients and lack of (oxidative) DNA damage in V79 Chinese hamster lung fibroblast cells at low levels of carvacrol and thymol. Food Chem Toxicol 47: 2037-2043, 2009.

62. Bhakkiyalakshmi E, Suganya N, Sireesh D, Krishnamurthi K, Saravana Devi S, Rajaguru P and Ramkumar KM: Carvacrol induces mitochondria-mediated apoptosis in HL-60 promyelocytic and Jurkat T lymphoma cells. Eur J Pharmacol 772: 92-98, 2016.

63. Spyridopoulou K, Fitsiou E, Bouloukosta E, Tiptiri-Kourpeti A, Vamvakias M, Oreopoulou A, Papavassilopoulou E, Pappa A and Chlichlia K: Extraction, chemical composition, and anticancer potential of Origanum onites L. essential oil. Molecules 24: 2612, 2019.

64. Liou G and Storz P: Reactive oxygen species in cancer. Free Radic Res 44: 479-496, 2010

65. Tayarani-Najaran Z, Asili J, Aioubi E and Emami SA: Growth inhibition and apoptosis induction of salvia chloroleuca on MCF-7 breast cancer cell line. Iran J Pharm Res 12: 789-799, 2013.

66. Kozics K, Klusová V, Srančíková A, Mučaji P, Slameňová D, Hunáková L, Kusznierewicz B and Horváthová E: Effects of Salvia officinalis and Thymus vulgaris on oxidant-induced DNA damage and antioxidant status in HepG2 cells. Food Chem 141: 2198-2206, 2013

67. Scholey AB, Tildesley NTJ, Ballard CG, Wesnes KA, Tasker A, Perry EK and Kennedy DO: An extract of Salvia (sage) with anticholinesterase properties improves memory and attention in healthy older volunteers. Psychopharmacology (Berl) 198: $127-139,2008$

68. Carrera-Quintanar L, Funes L, Viudes E, Tur J, Micol V, Roche E and Pons A: Antioxidant effect of lemon verbena extracts in lymphocytes of university students performing aerobic training program. Scand J Med Sci Sports 22: 454-461, 2012.

69. Fitsiou E, Mitropoulou G, Spyridopoulou K, Vamvakias M, Bardouki H, Galanis A, Chlichlia K, Kourkoutas Y, Panayiotidis MI and Pappa A: Chemical composition and evaluation of the biological properties of the essential oil of the dietary phytochemical lippia citriodora. Molecules 23: 123, 2018.

70. Malekirad A, Hosseini N and Bayrami M: Benefit of lemon verbena in healthy subjects; Targeting diseases associated with oxidative StRESS. Asian J Anim Vet Adv 6: 953-957, 2011

71. Tagde A, Singh H, Kang MH and Reynolds CP: The glutathione synthesis inhibitor buthionine sulfoximine synergistically enhanced melphalan activity against preclinical models of multiple myeloma. Blood Cancer J 4: e229, 2014

72. Rodman SN, Spence JM, Ronnfeldt TJ, Zhu Y, Solst SR, O'Neill RA, Allen BG, Guan X, Spitz DR and Fath MA: Enhancement of radiation response in breast cancer stem cells by inhibition of thioredoxin- and glutathione-dependent metabolism. Radiat Res 186: 385-395, 2016.

73. Petiwala SM, Berhe S, Li G, Puthenveetil AG, Rahman O, Nonn L and Johnson JJ: Rosemary (Rosmarinus officinalis) extract modulates CHOP/GADD153 to promote androgen receptor degradation and decreases xenograft tumor growth. PLoS One 9: e89772, 2014 
74. Olivares A, Alcaraz-Saura M, Achel DG and Alcaraz M: Effect of rosmarinic acid and ionizing radiation on glutathione in melanoma B16F10 cells: A translational opportunity. Antioxidants (Basel) 9: 1291, 2020.

75. Zhong Z, Qiang WW, Tan W, Zhang H, Wang S, Wang C, Qiang W and Wang Y: Chinese herbs interfering with cancer reprogramming metabolism. Evid Based Complement Alternat Med 2016: 9282813, 2016.

76. Karydas C, Iatrou M, Kouretas D, Patouna A, Iatrou G, Lazos N, Gewehr S, Tseni X, Tekos F, Zartaloudis Z, et al: Prediction of antioxidant activity of cherry fruits from UAS multispectral imagery using machine learning. Antioxidants (Basel) 9: 156, 2020.

77. Dorman HJD, Kosar M, Kahlos K, Holm Y and Hiltunen R: Antioxidant properties and composition of aqueous extracts from Mentha species, hybrids, varieties, and cultivars. J Agric Food Chem 51: 4563-4569, 2003.

78. Mantle D, Eddeb F and Pickering AT: Comparison of relative antioxidant activities of British medicinal plant species in vitro. J Ethnopharmacol 72: 47-51, 2000.
79. Matkowski A and Piotrowska M: Antioxidant and free radical scavenging activities of some medicinal plants from the Lamiaceae. Fitoterapia 77: 346-353, 2006.

80. Aruoma O: Methodological considerations for characterizing potential antioxidant actions of bioactive components in plant foods. Mutat Res 523-524: 9-20, 2003

81. Fatima N and Nayeem N: Toxic Effects as a Result of Herbal Medicine Intake. IntechOpen, London, 2016. https://www.intechopen.com/chapters/51762. Accessed October 26, 2016.

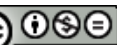

This work is licensed under a Creative Commons Attribution-NonCommercial-NoDerivatives 4.0 International (CC BY-NC-ND 4.0) License. 